Vol. 5 (1996): 541-546.

\title{
Detection of bovine foetal DNA from amniotic fluid using the polymerase chain reaction
}

Jaana Peippo and Peter Bredbacka

Agricultural Research Centre of Finland, Institute of Animal Production, FIN-31600 Jokioinen, Finland, e-mail: jaana.peippo@mtt.fi

\begin{abstract}
The aims of this study were to evaluate the amount of amniotic fluid required for diagnosis of sex, milk protein and microsatellite variants by polymerase chain reaction (PCR) and to review methods for isolating DNA from the amniotic cells. Uterine and foetal tissues were used as controls, and milk protein and microsatellite variants to check contamination of maternal cells in the PCR. The results showed that the samples do not need to be purified after DNA release from the amniotic cells and that as little as $0.5-1.5 \mathrm{ml}$ of amniotic fluid is sufficient for reliable diagnosis by PCR.
\end{abstract}

Key words: PCR, amniotic cells, sex determination, kappa-casein, microsatellites

\section{Introduction}

The polymerase chain reaction (PCR) (Saiki et al. 1988) offers a powerful tool for foetal diagnosis, allowing detection of small quantities of foetal cells from amniotic fluid without prior cell culture. In humans, foetal cells from the first trimester amniotic fluid have been widely used for various PCR-based diagnostic purposes including determination of sex (Pinckert et al. 1989, Kurauchi et al. 1992), solving the question of paternity (Nata et al. 1993), and detection of pathogenic organisms such as toxoplasma gondii (Dupouy-Camet et al. 1990, Grover et al. 1990) or human pavrovirus B19 (Koch and Adler 1990) and for estimation of chromosome
21 copy number by quantitative PCR (von Eggeling et al. 1993). Methods for PCR screening of a variety of infectious agents are also available in veterinary medicine (for review, see Pfeffer et al. 1995), but have not yet been used very often at the prenatal stage. In cattle, prenatal diagnosis by PCR has been used for detecting bovine citrullinaemia (Healy et al. 1993) and foetal sex (Kadokawa et al. 1995) and for determination of sex and transgene incorporation from a foetus produced by DNA microinjection at the pronuclear stage (Hyttinen et al. 1994).

In cattle, there are situations in which it would be valuable to know the sex of the foetuses of pregnant heifers. This can be ascertained by examining the foetal genitals with ultrasound. However, the time within which such an exami- 


\section{AGRICULTURAL AND FOOD SCIENCE IN FINLAND}

Peippo, J. \& Bredbacka, P. Detection of DNA from amniotic fluid

nation can be carried out is short, and usually several examinations have to be made to achieve efficiency approaching 100\% (Curran 1992). Thus it may often be both more practical and safer to analyse cells from the amniotic fluid. Possible risks for pregnancies caused by amniocentesis in cattle have been described by Leibo and Rall (1990).

In cattle, an amniotic fluid sample can be taken from a living animal either through a flank incision at 2 to 5 months of pregnancy (Leibo and Rall 1990, Healy et al. 1993, Hyttinen et al. 1994) or transvaginally at 2 to 9 months of pregnancy (Kadokawa et al. 1995) under local anaesthetic. The advantage of using amniotic rather than embryonic cells is that loss of pregnancy is avoided as there is no need to manipulate the embryo. Moreover, the timing of postimplantation diagnosis is not so strictly limited as is that of preimplantation diagnosis. Amniotic fluid analysis can also be used to complement preimplantation diagnosis, and unwanted foetuses can be detected and aborted.

In this study, cells were harvested by centrifugation from various amounts of amniotic fluid collected from uteri of slaughtered pregnant cows. The amniotic fluid samples were then used for diagnosis of sex (Y-chromosomal DNA) by PCR. To distinguish between foetal and maternal cells, analyses of $\mathrm{K}$-casein variants (A, B and $\mathrm{E}$ ) and, when necessary, microsatellite loci were performed.

\section{Material and methods}

\section{Sample collection and preparation}

Ten uteri from pregnant cows were collected at a slaughterhouse. The uteri were carefully dissected in the laboratory and samples from each foetus and uterus and the amniotic fluid were collected. The amniotic fluid was collected through the amniotic membrane using an $18 \mathrm{G}$ needle attached to a $10 \mathrm{ml}$ syringe. DNA was purified from $<5 \mathrm{~mm}^{3}$ pieces of foetal and uterine tissue by the procedure used for purifying DNA from human nucleated cells (Miller et al. 1988). From the first five foetuses, $1.5-10 \mathrm{ml}$ replicates of amniotic fluid were collected and purified after proteinase $\mathrm{K}$ treatment (Higuchi 1989) to increase DNA yield. The purified DNA was diluted with $100 \mu \mathrm{l}$ of distilled water. From all except the first three uteri, 0.5-1.5-ml amniotic fluid samples were also collected and these small volumes were treated with $25-100 \mu \mathrm{l}$ of proteinase $\mathrm{K}$ solution after being harvested by spinning. After proteinase $\mathrm{K}$ inactivation (10 min at $98^{\circ} \mathrm{C}$ ), these latter samples were used for diagnosis without further purification. Large volumes (in 10-ml tubes) were centrifuged at $3000 \mathrm{G}$ and small volumes in eppendorf tubes at 13000 $\mathrm{G}$, all at room temperature for $30 \mathrm{~min}$. All amniotic fluid samples were stored frozen at $-20^{\circ} \mathrm{C}$ before analysis. One $\mu$ of the purified and 1 or $5 \mu \mathrm{l}$ of the unpurified amniotic fluid were used for a PCR reaction.

\section{Diagnosis by PCR}

All foetuses were diagnosed for phenotypic sex and by PCR. All PCR samples (uterus, foetus and amniotic fluid replicates, $1 \mu \mathrm{l} /$ each PCR reaction) were diagnosed for sex according to Bredbacka and Peippo (1992) using the embryo sexing method based on restriction fragment length polymorphism analysis of the ZFY/ZFX locus (Fig. 1). Amplifications were performed using an MJ Minicycler (MJ Research, Inc., Watertown, MA, USA)

To verify the origin of DNA (foetal or maternal), the samples $(1 \mu \mathrm{l} /$ each PCR reaction) were also diagnosed for milk protein variants, $\kappa$-casein A, B and E alleles (Fig. 2), according to Medrano and Aguilar-Cordova (1990) with modifications described by Velmala et al. (1993). Amplifications were performed using the MJ Minicycler.

If there was no difference between the foetus and the dam in either sex or $\kappa$-casein variants, samples were studied for microsatellite 


\section{AGRICULTURAL AND FOOD SCIENCE IN FINLAND}

Vol. 5 (1996): 541-546.

Fig. 1. Banding patterns from male (lanes 1-8) and female (lane 9) samples after amplification of the ZFY/ZFX loci followed by digestion of the resulting product with PstI restriction endonuclease. Lines 1-7 represent replicates of amniotic fluid samples: $0.5 \mathrm{ml}$ (lanes 1-3), $1 \mathrm{ml}$ (lanes 3-6) and $1.5 \mathrm{ml}$ (lane 7) aspirated originally. Lanes 8-10 are controls: foetus, dam and a negative control (sample replaced with water), respectively. Lane 11 is a molecular size marker. (Photo: Jaana Peippo).

Fig. 2. An example of kappa-casein genotypes after amplification of the kappa-casein locus followed by digestion of the resulting product with HaeIII (lanes 3, 5, 7 and 10) and Hinfl (lanes 2, 4,6 and 9) restriction endonucleases. Lanes $2-$ 3 and 4-5 represent amniotic fluid replicates, lanes 6-7 foetus and 9-10 dam, respectively. The kappa-casein genotypes are BE for the foetus and $\mathrm{AE}$ for the dam. Lane 1 is a negative control, where the sample DNA is replaced with water and lane 8 is a molecular size marker. (Photo: Jaana Peippo).
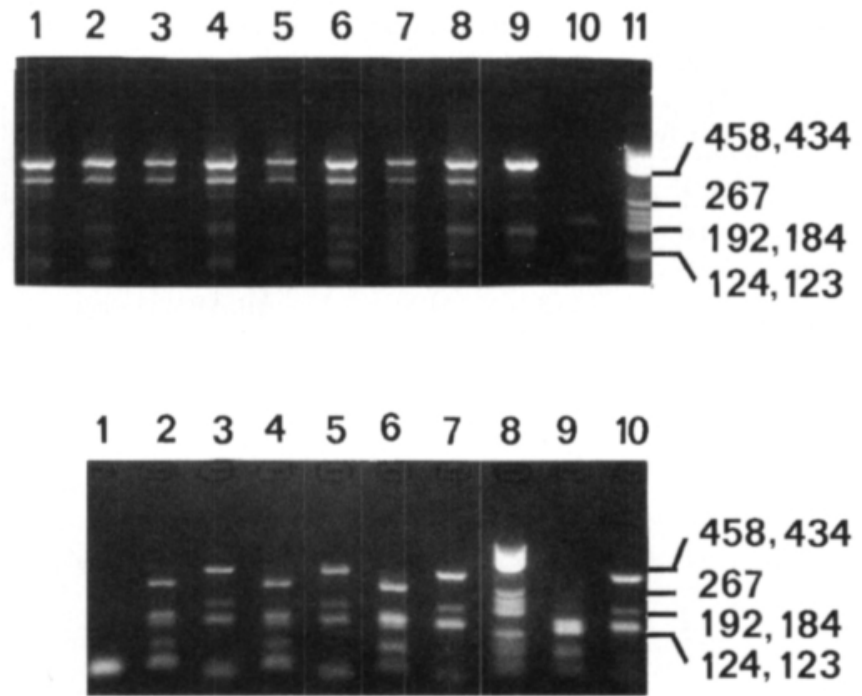

polymorphism using three different sets of primers: BoLA (Creighton et al. 1992), and HEL 5 and HEL 10 (Kaukinen and Varvio 1993). The latter two primer pairs were amplified in the same reaction in a final volume of $25 \mu \mathrm{l}$. The final assay conditions were: $50 \mathrm{ng}$ of sample DNA or $5 \mu$ of centrifuged and proteinase Ktreated amniotic cells, $0.8 \mathrm{mM}$ dNTPs (Finnzymes, Espoo, Finland), 10 pmol of each primer and $1 \mathrm{IU}$ of thermostable DNA polymerase (DynaZyme ${ }^{\mathrm{TM}}$, Finnzymes) in PCR buffer (10 $\mathrm{mM}$ Tris- $\mathrm{HCl}\left(\mathrm{pH} 7.4\right.$ at $\left.25^{\circ} \mathrm{C}\right), 1.5 \mathrm{mM} \mathrm{MgCl}_{2}$, $50 \mathrm{mM} \mathrm{KCl,} \mathrm{0.1 \%} \mathrm{Triton} \mathrm{X-100;} \mathrm{Finnzymes).}$ Samples were amplified using a PTC- $100^{\mathrm{TM}}$ Programmable Thermal Cycler (MJ Research, Inc.) as follows: $5 \mathrm{~min}$ initial denaturation at $94^{\circ} \mathrm{C}$ followed by $30 \mathrm{~s}$ at $94^{\circ} \mathrm{C}, 1 \mathrm{~min}$ at $55^{\circ} \mathrm{C}$ and 35 $\mathrm{s}$ at $72^{\circ} \mathrm{C}$ for 27 cycles. A final extension at $72^{\circ} \mathrm{C}$ for $8 \mathrm{~min}$ completed each amplification session. The fluorescein- labelled PCR products were separated on $6 \%$ denaturing PAGE gel (ReadyMix, Pharmacia, Uppsala, Sweden) using the Automated Laser Fluorescent DNA Sequencer (Pharmacia). Size was determined with an inter- nal size standard included in each lane. The gels were analysed using the Fragment Manager V1.1 program (Pharmacia).

\section{Results}

Five of the 10 uteri collected contained a female and five a male foetus. Sexes were easily identified from the phenotype of each foetus of 9 to $33 \mathrm{~cm}$ in size (i.e. approximately 70 to 120 days of age according to Noakes 1986). Amplification was successful on all the replicates of amniotic fluid analysed, and correct signals were obtained each time except that a single replicate from two foetuses with original volumes of 10 $\mathrm{ml}$ did not result in any amplification in PCR. In these cases the pellets of cells were probably lost during the purification process. The results for sex, $\kappa$-casein and microsatellite typing are summarized in Table 1. 


\section{Peippo, J. \& Bredbacka, P. Detection of DNA from amniotic fluid}

Table 1. Results of sex, kappa-casein (K-Cn) and microsatellite analysis of foetuses and their dams.

\begin{tabular}{|c|c|c|c|c|c|c|c|}
\hline Date & $\begin{array}{l}\text { Foetus } \\
\text { size }(\mathrm{cm})\end{array}$ & $\begin{array}{l}\text { Fluid } \\
\text { (ml) }\end{array}$ & $\begin{array}{l}\text { Sex: } \\
\text { phenot/PCR }\end{array}$ & $\begin{array}{l}\text { K-Cn: } \\
\text { dam/foetus }\end{array}$ & Microsa & $\begin{array}{l}\text { Ilite (dam;foetus): } \\
\text { HEL } 5\end{array}$ & HEL 10 \\
\hline 26.5 & 13.5 & $4 \times 10$ & $\mathrm{~F} / \mathrm{F}$ & $\mathrm{BE} / \mathrm{AB}$ & n.a. & n.a. & n.a. \\
\hline 07.6 & 10.5 & $6 \times 10$ & $\mathrm{~F} / \mathrm{F}$ & $\mathrm{AA} / \mathrm{AB}$ & n.a. & n.a. & n.a. \\
\hline 08.6 & 33.0 & $3 \times 10$ & $\mathrm{M} / \mathrm{M}$ & $\mathrm{AA} / \mathrm{AA}$ & n.a. & n.a. & n.a. \\
\hline 14.6 & 16.0 & $\begin{array}{l}1 \times 3 \\
4 \times 1.5\end{array}$ & $\mathrm{M} / \mathrm{M}$ & $\mathrm{AB} / \mathrm{AB}$ & n.a. & n.a. & n.a. \\
\hline 26.7 & 18.5 & $\begin{array}{l}2 \times 10 \\
6 \times 1.5 \\
6 \times 1\end{array}$ & $\mathrm{~F} / \mathrm{F}$ & $\mathrm{AA} / \mathrm{AE}$ & n.a. & n.a. & n.a. \\
\hline \multirow[t]{2}{*}{02.8} & 9.0 & $\begin{array}{l}6 \times 1.5 \\
6 \times 1\end{array}$ & $\mathrm{~F} / \mathrm{F}$ & $\mathrm{AE} / \mathrm{AE}$ & $124 / 134 ; 126 / 134$ & $152 / 162 ; 162 / 162$ & $102 / 102 ; 102 / 102$ \\
\hline & 13.0 & $\begin{array}{l}6 \times 1.5 \\
6 \times 1\end{array}$ & $\mathrm{M} / \mathrm{M}$ & $\mathrm{AE} / \mathrm{BE}$ & n.a. & n.a. & n.a. \\
\hline \multirow[t]{2}{*}{03.8} & 12.5 & $\begin{array}{l}6 \times 1.5 \\
6 \times 1\end{array}$ & $\mathrm{M} / \mathrm{M}$ & $\mathrm{AA} / \mathrm{AE}$ & n.a. & n.a. & n.a. \\
\hline & 16.5 & $\begin{array}{l}6 \times 1.5 \\
6 \times 1\end{array}$ & $\mathrm{~F} / \mathrm{F}$ & $\mathrm{AA} / \mathrm{AA}$ & $126 / 136 ; 126 / 130$ & $152 / 164 ; 152 / 162$ & $102 / 108 ; 108 / 108$ \\
\hline 09.8 & 25.0 & $\begin{array}{l}2 \times 1.5 \\
4 \times 1 \\
6 \times 0.5\end{array}$ & $\mathrm{M} / \mathrm{M}$ & $\mathrm{AA} / \mathrm{AA}$ & n.a. & n.a. & n.a. \\
\hline
\end{tabular}

n.a.= not analysed

\section{Discussion}

We show here that as little as $1 \mu \mathrm{l}$ of proteinase $\mathrm{K}$-treated amniotic fluid $(0.5 \mathrm{ml}$ aspirated originally) contains a sufficient amount of foetal cells for analysis of single copy genes by PCR followed by restriction fragment length polymorphism analysis. Furthermore, the amniotic fluid sample DNA does not need to be purified; on the contrary, cellular material may be lost during purification. The uniform and strong bands on the electrophoresis gels imply that parallel samples contained a cell number clearly exceeding the critical number for successful PCR. Hence the protocol may not be sensitive to variations in cell concentrations, at least in unpurified samples.

Maternal cell contamination is a potential source of misdiagnosis in amniotic fluid assays. Benn and Hsu (1983) reported that such contamination was relatively low $(0 \%$ to $0.543 \%)$ in humans. We used molecular markers to verify that the DNA analysed was of foetal rather than maternal origin. In all instances, the foetal origin of DNA could be confirmed by either sex determination, or $\kappa$-casein or microsatellite analysis. Highly polymorphic microsatellite loci are ideal for this purpose and have previously been used in humans, too (Rebello et al. 1994, Smith et al. 1995). In our study only foetal membranes were penetrated for aspiration of amniotic fluid with a needle. In practice, however, aspiration may have to be performed transvaginally, a procedure that certainly increases the risk of maternal cell contamination. When samples are taken for sex determination it is, however, unlikely that minor contamination will inhibit the amplification of Y-chromosomal DNA. Consequently, identification of foetal DNA in the sample should be sufficient for successful analysis.

The PCR approach can be used over a longer period during pregnancy than sexing of foetuses by ultrasound. We have amplified Y-cromosom- 
Vol. 5 (1996): 541-546.

al DNA from the amniotic fluid of a foetus $4 \mathrm{~cm}$ in size, equivalent to an age of 45-50 days, i.e. too young to be diagnosed by ultrasound.

Application of the postimplantation diagnosis described here may be useful in some commercial and research situations, e.g. when pregnant heifers are to be sold or the purity of X- or Y-separated sperm populations has to be tested after artificial inseminations.

The ethical aspects of amniocentesis should also be considered. If abortion may be a consequence of testing amniotic fluid samples, one should also consider alternative approaches, such as preimplantation diagnosis.

Acknowledgements. We wish to thank the LSO abattoir in Forssa for providing the uteri and Anneli Virta for performing the fragment analysis with the ALF. The technical assistance of Juha Kantanen, Reija Laitinen and Tuula-Marjatta Nieminen is greatly appreciated.

\section{References}

Benn, P.A. \& Hsu, L.Y.F. 1983. Maternal cell contamination of amniotic fluid cell cultures: results of a US nationwide survey. Journal of Medical Genetics 15: 297-305.

Bredbacka, P. \& Peippo, J. 1992. Sex diagnosis of ovine and bovine embryos by enzymatic amplification and digestion of DNA from the ZFY/ZFX locus. Agricultural Science in Finland 2: 233-238.

Creighton, P., Eggen, A., Fries, R., Jordan, S.A., Hetzel, J., Cunningham, E.P. \& Humphries, P. 1992. Mapping of bovine markers CYP21, PRL and BOLA DRBP1 by genetic linkage analysis in reference pedigrees. Genomics 14: 526-528.

Curran, S. 1992. Fetal sex determination in cattle and horses by ultrasonography. Theriogenology 37: 17-21.

Dupouy-Camet, J., Lavareda De Souza, S., Bougnoux, M.E., Mandelbrot, L., Hennequin, C., Dommergues, M., Benarous, R. \& Tourte-Schaffer, C. 1990. Preventing congenital toxoplasmosis. The Lancet 336: 8721, 10171018.

Grover, C.M., Thulliez, P., Remington, J.S. \& Boothroyd, J.C. 1990. Rapid prenatal diagnosis of congenital toxoplasma infection by using polymerase chain reaction and amniotic fluid. Journal of Clinical Microbiology 28: 2297-2301.

Healey, P., Dennis, J., Rawlinson, R. \& Andersson, L. 1993. Prenatal diagnosis of bovine citrullinaemia. Research in Veterinary Science 55: 271-274.

Higuchi, R. 1989. Simple and rapid preparation of samples for PCR. In: Erlich, H.A. (ed.). PCR technology. Principles and applications for DNA amplification. Stockton Press, N.Y. p. 31-38.

Hyttinen, J.-M., Peura, T., Tolvanen, M., Aalto, J., Alhonen, L., Sinervirta, R., Halmekytö, M., Myöhänen, S. \& Jänne, J. 1994. Generation of transgenic dairy cattle from transgene-analyzed and sexed embryos produced in vitro. Bio/Technology 12: 606-608.

Kadokawa, H., Minezawa, M., Takusari, N., Takahashi, H., Sasaki, O. \& Kariya, T. 1995. Detection of bovine fetal DNA by polymerase chain reaction for prenatal sexing. Theriogenology 43: 242 (Abstract).
Kaukinen, J. \& Varvio, S.-L. 1993. Molecular genetic markers. Eight polymorphic bovine microsatellites. Animal Genetics 24: 148.

Koch, W.C. \& Adler, S.P. 1990. Detection of human parvovirus B19 DNA by using the polymerase chain reaction. Journal of Clinical Microbiology 28: 65-69.

Kurauchi, O., Yagami, H., Kasugai, M., Mizutani, S. \& Tomoda, Y. 1992. Rapid determination of fetal sex using amniotic fluid cells and the polymerase chain reaction. Archives of Gynecology and Obstetrics 251: 145-148.

Leibo, S.P. \& Rall, W.F. 1990. Prenatal diagnosis of sex in bovine fetuses by amniocentesis. Theriogenology 33: 531-552.

Medrano, J.F. \& Aguilar-Cordova, E. 1990. Genotyping of bovine kappa-casein loci following DNA sequence amplification. Bio/Technology 8: 144-146.

Miller, S.A., Dykes, D.D. \& Polesky, H.F. 1988. A simple salting out procedure for extracting DNA from human nucleated cells. Nucleic Acids Research 16: 1215.

Nata, M., Nagae, M., Aoki, Y., Sagisasa, K. \& Uehara, S. 1993. Prenatal paternity testing with DNA analyses. International Journal of Legal Medicine 106: 160-162.

Noakes, D.E. 1986. Library of veterinary practice. Fertility and obstetrics in cattle. 1st ed. Blackwell Scientific Publications, London. 25 p.

Pfeffer, M., Wiedmann, M. \& Batt, C.A. 1995. Applications of DNA amplification techniques in veterinary diagnostics. A Review. Veterinary Research Communications 19: $375-407$.

Pinckert, T.L., Lebo, R.V. \& Golbus, M.S. 1989. Rapid determination of fetal sex by deoxyribonucleic acid amplification of $Y$ chromosome-specific sequences. American Journal of Obstetrics and Gynegology 161: 693-698. Rebello, M.T., Abas, A., Nicolaides, K. \& Coleman, D.V. 1994. Maternal contamination of amniotic fluid demonstrated by DNA analysis. Prenatal Diagnosis 14: 109112.

Saiki, R.K., Gelfand, D.H., Stoffel, S., Scharf, S.J., Higuchi, R., Horn, G.T., Mullis, K.B. \& Erlich, H.A. 1988. Primer-directed enzymatic amplification of DNA with a 
Peippo, J. \& Bredbacka, P. Detection of DNA from amniotic fluid

thermostable DNA polymerase. Science 239: 487-491. Smith, G.W., Graham, C.A., Nevin, J. \& Nevin, N.C. 1995. Detection of maternal cell contamination in amniotic fluid cell cultures using fluorescent labelled microsatellites. Journal of Medical Genetics 32: 61-64.

Velmala, R., Mäntysaari, E. \& Mäki-Tanila, A. 1993.
Molecular genetic polymorphism at the $\kappa$-casein and $\beta$-lactoglobulin loci in finnish dairy bulls. Agricultural Science in Finland 2: 431- 434.

Von Eggeling, F., Freytag, M., Fahsold, R., Horsthemke, B. \& Claussen, U. 1993. Rapid detection of trisomy 21 by quantitative PCR. Human Genetics 91: 567-570.

\title{
SELOSTUS
}

\section{Sikiön DNA:n tunnistaminen naudan sikiövedestä polymeraasiketjureaktion avulla}

\author{
Jaana Peippo ja Peter Bredbacka \\ Maatalouden tutkimuskeskus
}

Sikiövedestä tehtävä diagnostiikka on tullut nopeammaksi ja tehokkaammaksi viime vuosikymmenellä keksityn polymeraasiketjureaktion (PCR) myötä. DNA:n voi nyt analysoida suoraan aspiroidusta sikiövesinäytteestä ilman soluviljelyä. Ihmislääketieteessä PCR:ään perustuva sikiövesidiagnostiikka on ollut käytössä jo useiden vuosien ajan. Valmius myös naudan perinnöllisten sairauksien ja taudinaiheuttajien toteamiseksi on jo olemassa, mutta menetelmiä ei ole vielä otettu yleisesti tähän käyttöön. Tässä kokeessa haluttiin selvittää, kuinka pienestä sikiövesinäytteestä sukupuolenmääritys voidaan luotettavasti tehdä, ja miten näyte on puhdistettava analyysiä varten.

Tutkimusta varten teurastamolta haettiin 10 kohtua 70-120 päivän ikäisine sikiöineen. Laboratoriossa kerättiin näytteet sikiövedestä, sikiöstä ja kohdusta. Sikiövedestä määritettiin sukupuoli ja kappa-kaseiini -tyyppi, jotta näytteen voitiin osoittaa sisältävän sikiön soluja. Jos emän ja sikiön välillä ei ollut kum- massakaan em. analyysissä eroa, tehtiin vielä mikrosatelliitteihin eli DNA:n toistojaksoihin perustuva analyysi. Mikrosatelliitteja esiintyy läpi koko genomin ja kunkin mikrosatelliittilokuksen muuntelu eri yksilöiden välillä on suurta, joten niiden joukosta on mahdollista valita sellaiset, joiden "sormenjäljet" ovat yksilölliset.

Kaikista sikiövesinäytteistä saatiin sama signaali kuin itse sikiöstä ja nämä molemmat poikkesivat emän signaalista. Kahdesta puhdistetusta sikiövesinäytteestä katosi soluaines puhdistuksen aikana, joten on yksinkertaisempaa ja turvallisempaa jättää näyte puhdistamatta, koska analyysin onnistuminen ei siitä vaarannu.

Tutkimuksen perusteella voidaan todeta, että kehittyvän sikiön sukupuoli ja tarvittaessa muitakin DNA-tasolla näkyviä ominaisuuksia voidaan luotettavasti määrittää suoraan $0,5-1,5 \mathrm{ml}$ :stä sikiövettä ilman edeltävää soluviljelyä tai DNA:n puhdistusta. 